16. Liu Q., Zhou Y.Q., He G.S., Oosthuizen M.C., Zhou D.N., Zhao J.L. Molecular phylogenetic studies on Theileria spp. isolates (China) based on small subunit ribosomal RNA gene sequences // Tropical Animal Health and Production, 2010, Vol. 42, P. 109-114.

17. Mans B.J., Pienaar R., Potgieter F.T., Latif A.A. Theileria parva, T. sp. (buffalo) and T. sp. (bougasvlei) $18 \mathrm{~S}$ variants // Veterinary Parasitology, 2011, Vol. 182, P. 382-383.

18. Mans B.J., Pienaar R., Latif A.A. A review of Theileria diagnostics and epidemiology // International Journal Parasitology: Parasites and Wildlife, 2015, Vol. 4, No. 1, P. 104-18.

19. Suarez C.E., Laughery J.M., Schneider D.A., Sondgeroth K.S., McElwain T.F. Acute and persistent infection by a transfected Mo7 strain of Babesia bovis // Molecular and Biochemical Parasitology, 2012, Vol. 185, P. 52-57.
20. Tamura K. and Nei M. Estimation of the number of nucleotide substitutions in the control region of mitochondrial DNA in humans and chimpanzees // Molecular Biology and Evolution, 1993, Vol. 10, P. 512-526.

Бурсаков Сергей Алексеевич, канд. биол. наук, старший научный сотрудник, ФГБНУ «Центр экспериментальной эмбриологии и репродуктивных биотехнологий». Россия.

Ковальчук Светлана Николаевна, канд. биол. наук, директор, ФГБНУ «Центр экспериментальной эмбриологии и репродуктивных биотехнологий». Россия.

127422, г. Москва, ул. Костякова, 12, стр. 4.

Тел.: (495) 610-21-31.

Ключевые слова: клещевые инфекции; Theileria spp.; крупный рогатый скот; Babesia spp.; Bos taurus.

\title{
DISTRIBUTION OF BOVINE THEILERIOSIS IN THE MOSCOW REGION
}

Bursakov Sergey Alekseevich, Candidate of Biological Sciences, Senior researcher, Federal State Budget Scientific Institution Center of Experimental Embryology and Reproductive Biotechnologies. Russia.

Kovalchuk Svetlana Nikolaevna, Candidate of Biological Sciences, Federal State Budget Scientific Institution Center of Experimental Embryology and Reproductive Biotechnologies. Russia.

Keywords: tick-borne disease; Theileria spp.; cattle; Babesia spp.; Bos Taurus.

The transmissible diseases of cattle caused by the pathogens Theileria and Babesia are highly hazardous to animals and lead to significant economic losses in cattle breeding. In this work, a molecular-genetic method was used to identify these pathogens in the blood of animals of one of the farms in the Moscow Region. The causative agent of babesiosis was not revealed, while the level of distribution of Theileria spp. fluctuated in significant range from 19 to $43 \%$, depending on seasonality. Identity from 97 to $100 \%$ to five different species of Theileria spp.was shown for the nucleotide sequences of the fragment of $18 \mathrm{~S}$ rRNA gene of the obtained Theileria spp. isolates. The obtained data on the level of infestation of cattle by Theileria spp. allow drawing attention to a problem that can play a significant role in the economic losses in the livestock in Russia.

\section{ВЛИЯНИЕ ЛЕСНОЙ ПОЛОСЫ НА ФОРМИРОВАНИЕ ЭКОЛОГИЧЕСКИХ ФАКТОРОВ АГРОЛАНДШАФТА}

\author{
ВЕРИН Александр Юрьевич, ФГБНУ «НИИСХ Юго-Востока» \\ МЕДВЕДЕВ Иван ФИлиппович, ФГБНУ «НИИСХ Юго-Востока» \\ ГУБАРЕВ Денис Иванович, ФГБНУ «НИИСХ Юго-Востока» \\ ДЕРЕВЯГИН Сергей Сергеевич, ФГБНУ «НИИСХ Юго-Востока» \\ ГРАФОВ Виктор Петрович, Аркадакская сельскохозяйственная опытная станция
}

Введение. Агроландшафт - целостная, внутренне неоднородная природно-сельскохозяйственная геосистема, включающая в себя как обрабатываемые земли, так и угодья иного функционального профиля [6]. Нарушение одного из объектов агроландшафта приводит к дисбалансу всей системы. Поддерживать нормальное функционирование агроландшафта позволяет применение различных мероприятий, направленных на устранение причин возникновения такого дисба- ланса. Наиболее распространенным мелиоративным мероприятием является размещение лесных полос. Защитные лесные насаждения участвуют в распределении снега на полях, улучшают микроклимат, а также влияют на агрофизические свойства и процессы, протекающие в почве [7].

Цель данной работы - выявить физико-биологические особенности формирования агроландшафта на примере чернозема южного, чернозема обыкновенно- 
го и каштановой почвы, на их естественных ценозах и на землях сельскохозяйственного назначения.

Методика исследований. Объектом исследования послужил агроландшафт на черноземе обыкновенном Ч (Аркадакская СХOC) Окско-Донской равнины Елань-Терсинского ландшафтного района (5151'55.1"N $\left.43^{\circ} 37^{\prime} 04.8^{\prime \prime E}\right)$, агроландшафт на черноземе южном

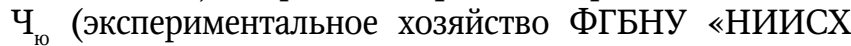
Юго-Востока») Приволжской возвышенности Чардымо-Курдюмского ландшафтного района $\left(51^{\circ} 35^{\prime} 43.0^{\prime \prime} \mathrm{N}\right.$ $\left.46^{\circ} 03^{\prime} 45.9^{\prime \prime} \mathrm{E}\right)$ и агроландшафт на каштановых почвах К (Краснокутская СОС НИИСХ Юго-Востока) Высокой Сыртовой равнины Еруслано-Бизюкского ландшафтного района (5054'27.1"N 4704'29.1"Е).

Почвенные образцы отбирали в строго установленных точках с привязкой координат: целина, пашня в открытом поле, пашня в зоне действия лесной полосы (8Н). Формирование физико-биологических особенностей почвы изучали под посевами яровой пшеницы. Отбор почвенных проб осуществляли в июле. При определении структурного состава почвы использовали ситовый метод. Нитрификационную способность почв устанавливали по методу Кравкова при 7-дневном компостировании. Плотность сложения, общую пористость, влажность, нитрификационную способность почвы определяли по общепринятым методикам. Для статистических расчетов использовали стандартные формулы математической обработки данных в компьютерной программе Excel.

Результаты исследований. В ходе изучения агроландшафтов на черноземе обыкновенном, черноземе южном и на каштановой почве было установлено, что их физические и водно-физические свойства в открытом поле существенно отличались от целинных. Также исследования показали, что почвы в зоне влияния лесной полосы в меньшей степени подвергались отрицательному воздействию обработок. По сравнению с открытым полем в слое почвы 0-30 см в зоне физико-биологического влияния лесной полосы структура почвы улучшилась по всем агроландшафтам. Уменьшилось (на 1,72 \%) количество глыбистой фракции (размером > 10 мм) для чернозема обыкновенного от 22,42 до 20,7 \%, для чернозема южного (на 0,8 \%) от 13,66 до 12,86 \%, для каштановой почвы (на 19,1\%) от 31,4 до 12,3 \%. По сравнению с целинным участком в открытом поле количество глыбистой фракции (размером >10 мм) увеличилось для чернозема обыкновенного (на $15,74 \%$ ) - от 6,68 до 22,42 \%, для чернозема южного(на 8,94 \%) - от 4,72 до 13,66 \%, для каштановой почвы (на 17,98 \%) - от 13,42 до 31,4 \%.

Увеличилась (на 5,5 \%) сумма структурных фракций меньших размеров (5-0,25 мм), средних, мелких комков и зернистых фракций для чернозема обыкновенного от 40,1 до 45,6 \%, для чернозема южного (на $6,54 \%$ - от 61,7 до 68,24 \%, для каштановой почвы (на $4,95 \%$ ) - от 46,40 до $66,65 \%$. В связи с отсутствием листового опада лесных полос в открытом поле сумма структурных фракций меньших размеров (5-0,25 мм), средних, мелких комков и зернистых фракций по сравнению с целинным участком уменьшилась (на 41,32 \%) для чернозема обыкновенного - с 81,42 до 40,1\%, для чернозема южного (на $18,42 \%$ ) - от 80,12 до 61,7 \%, для каштановой почвы (на $14,78 \%$ ) - от 61,18 до $46,4 \%$ (табл. 1 ).

По количеству агрономически ценных агрегатов (10-0,25 мм) окультуривание исследуемых почв привело к ухудшению их структурного состояния. Для целинного участка чернозема обыкновенного содержание ценных агрегатов по результатам сухого рассева составило 91,06 \%, водопрочных - 72,24\%, для почвы в открытом поле оно снизилось до 66,54 и $60,1 \%$, то есть на 24,52 и 12,14\%. В зоне влияния лесной полосы почва менее подвергалась изменению при окультуривании - 73,9 и 64,2 \%. Для целинного участка чернозема южного содержание ценных агрегатов составило 90,06 \%, водопрочных 81,22 \%, для почвы в открытом поле оно снизилось до 75,25 и 61,56\%, то есть на 15,35 и 19,66 \%. В зоне влияния лесной полосы почва в меньшей степени подвергалась изменению при окультуривании. Содержание ценных агрегатов диагностировалось на уровне $80,3 \%$, а водопрочных - 63,47 \%. Целинный участок каштановой почвы содержал 78,64 \% ценных агрегатов и 77,84 \% водопрочных, в то время как на открытом участке поля оно снизилось на 13,84 и 23,24 \%. В зоне влияния лесной полосы почва подвергалась изменению при окультуривании меньше, чем на открытом участке. Количество водопрочных агрегатов снизилось на 19,94\%, а содержание ценных агрегатов всего на 4,81 \% по сравнению с целиной.

Полученные данные показали, что окультуренная почва чернозема обыкновенного в 1,2 раза утратила количество водопрочных агрегатов по сравнению с целинным аналогом. По величине коэффициента структурности агрегатное состояние на всех исследуемых зонах чернозема обыкновенного оказалось различным. Максимальная величина коэффициента структурности выявлена на целине $(10,07)$, минимальная - на почве в открытом поле $(1,98)$. На интенсивно используемой пашне чернозема южного количество водопрочных агрегатов уменьшилось в 1,3 раза по сравнению с целиной. Наибольший коэффициент структурности оказался на целине чернозема южного $(9,06)$, минимальный - на почве в открытом поле $(3,04)$. Каштановая почва, имея наименьший по мощности гумусовый профиль, наиболее сильно подвергалась деградации. На обрабатываемой пашне за время ее использования в сельскохозяйственном производстве в 1,4 раза снизилось количество водопрочных агрегатов. По величине коэффициента структурности каштановых почв агрегатное состояние на целине диагностировали как максимальное $(3,68)$, минимальный коэффициент отмечали на почве в открытом поле $(1,84)$. С уменьшением количества физической глины в почве величина коэффициента структурности возрастала за счет снижения доли микроагрегатов.

По величине критерия водопрочности агрегатов максимальный его показатель отмечали у чернозема южного на целине $(810,3)$, что характеризует еекакценоз с отличной водопрочностью агрегатов. В зоне действия лесной полосы водопрочность агрегатов очень хорошая $(511,5)$, а в открытом поле она оказалась неудовлетворительной $(18,75)$. Для чернозема обыкновенного очень хорошая водопрочность агрегатов отмечалась на целине $(722,2)$, хорошая - в зоне действия лесной полосы $(253,9)$, а неудовлетворительная - в открытом поле $(12,43)$. Аналогично двум другим подтипам почвы для каштановой почвы хорошей водопрочностью агрегатов отличалась целина $(135,2)$, а в зоне действия лесной полосы и на открытом поле - неудовлетворительная (49,13 и 22,08 соответственно).

Одним из основных факторов, характеризующих агрофизические свойства почвы, является плотность 
Структурный состав по сухому и мокрому рассеву в слое почвы 0-30 см

\begin{tabular}{|c|c|c|c|c|c|c|c|c|c|c|c|c|c|}
\hline \multirow{2}{*}{ Почва* } & \multicolumn{9}{|c|}{ Фракция (мм), \%, Сухой рассев*** / Мокрый рассев } & \multicolumn{2}{|c|}{ Сумма фракций } & \multirow{2}{*}{ Кс } & \multirow{2}{*}{ Кв } \\
\hline & $>10$ & $10-7$ & $7-5$ & $5-3$ & $3-2$ & $2-1$ & $1-0,5$ & $0,5-0,25$ & $<0.25$ & $>10$ и $<0,25$ & $10-0,25$ & & \\
\hline \multicolumn{14}{|c|}{ Целина** } \\
\hline \multirow{2}{*}{$\mathrm{Y}_{\mathrm{o}}$} & 6,68 & 11,9 & 11,3 & 10,4 & 28,24 & 21,64 & 3,28 & 4,3 & 2,26 & 8,94 & 91,06 & \multirow{2}{*}{10,07} & \multirow{2}{*}{722,2} \\
\hline & - & - & $\overline{0,32}$ & $\overline{0,37}$ & 9,4 & $\overline{40,1}$ & 17,62 & 1,22 & $\overline{30,97}$ & 30,97 & $\overline{69,03}$ & & \\
\hline \multirow[b]{2}{*}{$\mathrm{Y}_{\text {ко }}$} & 4,72 & 9,44 & $\underline{13,22}$ & 8,36 & 22,48 & 28,24 & 4,38 & 3,44 & 26,1 & $\underline{9,94}$ & 90,06 & \multirow[b]{2}{*}{9,06} & \multirow{2}{*}{810,3} \\
\hline & - & - & $\overline{0,24}$ & $\overline{0,9}$ & $\overline{12,48}$ & $\overline{48,02}$ & $\overline{19,4}$ & $\overline{0,18}$ & $\overline{27,6}$ & $\overline{27,6}$ & $\overline{72,4}$ & & \\
\hline \multirow{2}{*}{$\mathrm{K}_{2}$} & 13,42 & 12 & 13,4 & 16,4 & 8,9 & 7,63 & 11,3 & 9,01 & 7,94 & 21,36 & 78,64 & \multirow{2}{*}{3,68} & \multirow{2}{*}{135,2} \\
\hline & - & - & 0,1 & 1,34 & 18,64 & 29,6 & 27,92 & 0,24 & 22,16 & 22,16 & 77,84 & & \\
\hline \multicolumn{14}{|c|}{ В зоне влияния лесной полосы** } \\
\hline \multirow{2}{*}{$\mathrm{Y}_{\mathrm{o}}$} & 20,7 & 9,1 & 11,3 & 11,3 & 10,2 & 17,9 & 7,9 & 6,2 & 5,4 & 26,1 & 73,9 & \multirow{2}{*}{2,83} & \multirow[b]{2}{*}{253,9} \\
\hline & - & - & $\overline{0,12}$ & $\overline{0,4}$ & $\overline{16,4}$ & $\overline{41}$ & $\overline{13,6}$ & $\overline{0,72}$ & $\overline{27,6}$ & $\overline{27,6}$ & $\overline{72,4}$ & & \\
\hline \multirow[b]{2}{*}{$\mathrm{Ч}_{\text {ко }}$} & 12,86 & 14,32 & 11,12 & 6,24 & 12,02 & 30,44 & 2,98 & 3,18 & 6,84 & 19,7 & 80,3 & \multirow{2}{*}{4,07} & \multirow[b]{2}{*}{511,5} \\
\hline & - & - & $\overline{1,48}$ & $\overline{10,42}$ & $\overline{10,42}$ & $\overline{28,58}$ & $\overline{2,42}$ & $\overline{0,14}$ & $\overline{46,52}$ & $\overline{46,52}$ & $\overline{53,48}$ & & \\
\hline \multirow{2}{*}{$\kappa_{2}$} & 12,3 & 11,05 & 10 & 13,8 & 8,6 & 15,21 & 12,64 & 7,06 & 9,34 & 21,64 & 78,36 & \multirow{2}{*}{3,62} & \multirow[b]{2}{*}{49,13} \\
\hline & - & - & $\overline{6,9}$ & $\overline{3,88}$ & $\overline{15,1}$ & $\overline{22,12}$ & 9,26 & $\overline{0,64}$ & $\overline{42,1}$ & 42,1 & $\overline{57,9}$ & & \\
\hline \multicolumn{14}{|c|}{ В открытом поле** } \\
\hline \multirow[b]{2}{*}{$\mathrm{Y}_{\mathrm{o}}$} & 22,42 & 11,62 & 9,36 & 5,48 & 11,92 & 16,1 & 3,42 & 8,64 & 11,04 & 33,46 & 66,54 & \multirow{2}{*}{1,98} & \multirow{2}{*}{12,43} \\
\hline & - & - & $\overline{1,64}$ & 25 & 47 & $\overline{1,06}$ & $\overline{0,44}$ & $\overline{0,16}$ & 24,7 & 24,7 & $\overline{75,3}$ & & \\
\hline $\mathrm{U}$ & 13,66 & 8,9 & 9,2 & 4,84 & 7,48 & 27,48 & 5,24 & 12,14 & 11,06 & 24,72 & 75,28 & 201 & 1875 \\
\hline $4_{10}$ & - & - & 2,46 & 19,84 & 35,76 & 2,96 & $\overline{0,3}$ & $\overline{0,24}$ & 38,42 & $\overline{38,42}$ & $\overline{61,58}$ & 3,04 & $18, / 5$ \\
\hline & 31,4 & 11,3 & 10,9 & 14,2 & 6,24 & 7,44 & 9,14 & 5,58 & 3,8 & 35,2 & 64,8 & & \\
\hline $\mathrm{K}_{2}$ & - & - & $\overline{9,42}$ & $\overline{3,84}$ & $\overline{11,26}$ & $\overline{25,64}$ & $\overline{4,02}$ & $\overline{0,42}$ & $\overline{45,4}$ & $\overline{45,4}$ & $\overline{54,6}$ & 1,84 & 22,08 \\
\hline Фактор & & & & 0,021 & & & & 3 , & & & & & 860 \\
\hline Факто & & & & 0,021 & & $F_{\text {теор }}$ & & 3 , & & $F_{\phi}$ & & & 118 \\
\hline Tор & & & & 0,037 & & & & 2, & & & & &, 94 \\
\hline
\end{tabular}

При мечан ие: Кс - коэффициент структурности; Кв - коэффициент водопрочности; числитель - содержание ценных агрегатов; знаменатель - содержание водопрочных агрегатов.

сложения. Она влияет на водный, воздушный и тепловой режимы почвы, а также на ее микробиологическую активность. Чем меньше плотность сложения, тем богаче может быть почва воздухом, водой и гумусом, тем благоприятнее она для возделывания сельскохозяйственных культур. Кроме того, плотность сложения имеет большое практическое значение, так как характеризует почву с точки зрения трудности ее обработки сельскохозяйственными орудиями $[1,2]$.

Плотность сложения на землях сельскохозяйственного использования (пашня) в верхнем пахотном слое почвы на всех вариантах агроландшафта выросла по сравнению с естественным аналогом (целина) в среднем на 0,26 г $/ \mathrm{cm}^{3}$. На каштановой почве плотность сложения

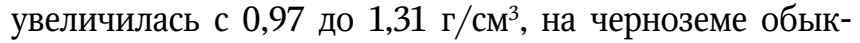

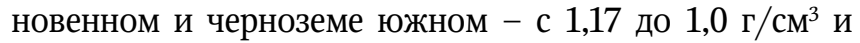

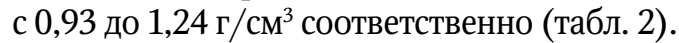

Ценным свойством структуры является ее пористость. В гумусовых горизонтах минеральных почв пористость обычно составляет 50-60 \% (в свежевспаханной почве пористость может быть больше 70 \%), постепенно уменьшаясь с глубиной [4]. Общая порозность почвы тесно взаимосвязана с ее плотностью и структурным состоянием и в значительной мере определяет водоудерживающую способность, движение влаги и минеральных солей в почвенном профиле, доступность влаги растениям, содержание в почве воздуха $[3,5]$.

С увеличением плотности сложения пористость почвы снижается. Для агроландшафта на черноземе обыкновенном наиболее благоприятную пористость почвы отмечали на целинном участке - 53,24 \%, постепенно снижаясь до 42,23 \% в открытом поле. На черноземе южном сильнее проявлялось уменьшение общей порозности - с 49,73 до 29,75 \%. Наибольшие

Таблица 2

Изменение агрофизических свойств почвы

в зоне влияния лесной полосы (слой почвы 0-30 см)

\begin{tabular}{|c|c|c|c|c|c|c|}
\hline Почва* & 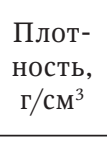 & $\begin{array}{c}\text { Пороз- } \\
\text { ность, \% }\end{array}$ & $\begin{array}{c}\text { Влаж- } \\
\text { ность, } \%\end{array}$ & $\begin{array}{l}\text { Валовый } \\
\text { гумус, \% }\end{array}$ & $\begin{array}{r}\text { Ни } \\
\text { ц } \\
\text { спо } \\
\end{array}$ & $\begin{array}{l}\text { трифика- } \\
\text { ционная } \\
\text { собность, } \\
\text { мг/кг }\end{array}$ \\
\hline \multicolumn{7}{|c|}{ Целина** } \\
\hline $\mathrm{Y}_{0}$ & $1,17^{* * *}$ & 53,24 & 19,82 & 5,64 & & 5,07 \\
\hline $\mathrm{Y}_{\mathrm{ro}}$ & 0,93 & 49,73 & 22,38 & 5,87 & & 6,78 \\
\hline $\mathrm{K}_{2}$ & 0,97 & 50,46 & 19,64 & 3,17 & & 3,69 \\
\hline \multicolumn{7}{|c|}{ В зоне влияния лесной полосы** } \\
\hline $\mathrm{\Psi}_{0}$ & 1,16 & 45,83 & 17,09 & 3,61 & & 4,74 \\
\hline $\mathrm{Y}_{\mathrm{ro}}$ & 1,19 & 43,41 & 22,56 & 4,62 & & 6,50 \\
\hline $\mathrm{K}_{2}$ & 1,23 & 30,52 & 19,21 & 3,04 & & 4,41 \\
\hline \multicolumn{7}{|c|}{ В открытом поле** } \\
\hline $\mathrm{\Psi}_{0}$ & 1,30 & 42,23 & 22,56 & 2,44 & & 4,15 \\
\hline $\mathrm{Y}_{\text {юо }}$ & 1,24 & 29,75 & 21,16 & 3,02 & & 4,06 \\
\hline $\mathrm{K}_{2}$ & 1,31 & 26,87 & 21,4 & 1,64 & & 4,61 \\
\hline $\begin{array}{c}\text { Фактор } \\
\text { A* }^{*}\end{array}$ & \multirow{3}{*}{$\mathrm{HCP}_{0,5}$} & 0,019 & \multirow{3}{*}{$F_{\text {теор }}$} & 3,09 & \multirow{3}{*}{$F_{\text {факт }}$} & 85,512 \\
\hline $\mathrm{B}^{* *}$ & & 0,019 & & 3,09 & & 60,822 \\
\hline $\mathrm{C}^{* * *}$ & & 0,024 & & 2,46 & & 28209,238 \\
\hline
\end{tabular}


различия отмечали для агроландшафта на каштановой почве - с 50,46 до 26,87 \%. Почвы, находящиеся в зоне влияния лесной полосы, в среднем на 7,2 \% меньше подвергались снижению порозности почвы.

Наиболее важную роль в повышении почвенного плодородия играют биологические процессы, активность которых зависит от почвенных условий. Чем лучше аэрация, увлажнение почвы, тем больше численность микроорганизмов, разлагающих органику. Тем самым ускоряется распад гумуса. Уровень нитрификационной способности почв тесно коррелирует с уровнем содержания гумуса в них $(r=0,64)$. Нитрификационная способность была максимальной на целинном участке чернозема южного 6,78 мг/кг при содержании гумуса в почве 5,87 \% и влажности почвы 22,38 \%. Для чернозема обыкновенного максимальная нитрификационная способность была на целине - 5,07 мг/кг при содержании гумуса в почве 5,64 \% и влажности почвы 19,82 \%. Для каштановой почвы максимальную нитрификационную способность отмечали в зоне влияния лесной полосы - 4,41 мг/кг при содержании гумуса в почве 3,04 \% и влажности почвы 19,21 \%. Гумус, являясь основным источником минерального азота, определяет величину нитрификационной способности. При содержании гумуса в почве менее $4 \%$ происходит сильное снижение нитрификационной способности почв, что непосредственно влияет на уровень их плодородия и продуктивность возделываемых культур в агроландшафте.

Заключение. Почвы, вовлеченные в сельскохозяйственное производство, изменяют структуру и воднофизические свойства. Количество агрономически ценных агрегатов в почве во всех агроландшафтах снизилось по сравнению с природными аналогами.

По мере приближения к лесной полосе происходит улучшение структуры почвы и ее водопрочности. Это связано с физико-биологическим влиянием лесных полос на близлежащие участи поля. Агрофизические показатели улучшаются благодаря физикобиологическому воздействию лесных полос. По сравнению с открытым участком поля в зоне действия лесных полос снижается плотность сложения почвы

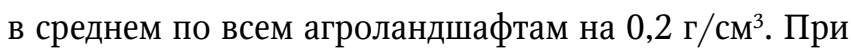
этом пористость почвы возрастает в среднем по всем агроландшафтам на 4,8 \%. На процессы нитрификации существенно влияет содержание гумуса в почве.

\section{СПИСОК ЛИТЕРАТУРЫ}

1. Алферов А.А., Сафонов А.Ф. Водопрочность структуры и плотность почвы // Длительному полевому опыту ТГСХ 90 лет: итоги научных исследований. - М.: Изд-во ТГСХА, 2002. - С. 109-125.

2. Гедройи К.К. К вопросу о почвенной структуре и сельскохозяйственном её значении // Изв. государ. ин-та опытной агрономии. - 1926. - Т. 4. - Вып. 3. - С. 15-22.

3. Качинский Н.А. Структура почвы. - М.: Изд-во Моск. ун-та, 1963. - 89 с.

4. Медведев И.Ф., Анисимов Д.А., Бочков А.А. Экологомелиоративные особенности развития почвенной системы в зоне влияния лесных полос // Вестник Саратовского госагроуниверситета им. Н.И. Вавилова. - 2013. - № 11. - С. 3-9.

5. Модина С.А., Долгов С.И., Польский М.Н. Сложение и структурное состояние почвы // Агрофизические методы исследования почв. - М.: Наука, 1966. - С. 42-71.

6. Николаев В.А. Концепция агроландшафта // Вестник МГУ. Сер. 5. География. - 1987. - № 2. - С. 22-27.

7. Самсонов Е. В. Воздействие лесных полос противоэрозионного комплекса на почвенные факторы и урожайность сельскохозяйственных культур в степи Приволжской возвышенности: автореф. дис. ... канд. с.-х. наук. - Саратов, 2006. - 19 с.

Верин Александр Юрьевич, младший научный сотрудник, ФГБНУ «НИИСХ Юго-Востока». Россия.

Медведев Иван Филиппович, $\partial-p$ c.- $x$. наук, проф., главный научный сотрудник, ФГБНУ «НИИСХ Юго-Востока». Россия.

Губарев Денис Иванович, канд. с.-х. наук, стариий научный сотрудник, ФГБНУ «НИИСХ Юго-Востока». Россия.

Деревягин Сергей Сергеевич, канд. с.-х. наук, зам. директора по науке, ФГБНУ «НИИСХ Юго-Востока». Россия.

410010, г. Саратов, ул. Тулайкова, 7.

Тел.: (8452) 64-76-88; e-mail: raiser saratov@mail.ru.

Графов Виктор Петрович, канд. с.-х. наук, директор, Аркадакская сельскохозяйственная опытная станция. Россия. 412214, Саратовская обл., Аркадакский р-н, с. Росташи, Школьный пер., 21А.

Тел.: (84542) 2-12-89.

Ключевые слова: агроландшафт; структура почвы; плотность сложения; пористость; влагоемкость; нитрификационная способность почвы.

\section{THE INFLUENCE OF THE FOREST BELT ON THE FORMATION OF THE ECOLOGICAL FACTORS OF THE AGROLANDSCAPE}

Verin Aleksandr Yuryevich, Younger Researcher, Research Agricultural Institute for South-East Region. Russia.

Medvedev Ivan Philippovich, Doctor of Agricultural Sciences, Professor, Chief Researcher, Research Agricultural Institute for South-East Region. Russia.

Gubarev Denis Ivanovich, Candidate of Agricultural Sciences, Senior Researcher, Research Agricultural Institute for South-East Region. Russia.

Derevyagin Sergey Sergeevich, Candidate of Agricultural Sciences, Research Agricultural Institute for South-East Region. Russia.

Graphov Viktor Petrovich, Candidate of Agricultural Sciences, Arkadak Agricultural Experiment Station. Russia.

Keywords: agrolandscape; soil structure; bulk density; porosity; moisture capacity; soil nitrification capacity.

Physical and biological features of agrolandscape formation are considered on the example of ordinary cher- nozem, southern chernozem, and chestnut soil. It is shown that as we approach the forest belt, there is an improvement in the soil structure and its water strength. The number of agronomically valuable units according to the results of dry and wet sifting on the soil of agricultural use is reduced in comparison with virgin soil. The forest belt compared to the open area of the field allows reducing the density of soil composition on average in all agricultural landscapes by $0.2 \mathrm{~g} / \mathrm{cm} 3$, while the porosity of the soil increases by $4.8 \%$. With an increase in the bulk density, the soil porosity decreases. In ordinary chernozem, the most favorable soil porosity is in the virgin area (53.24\%), it gradually decreases to $42.23 \%$ in the soil in an open field; in southern chernozem - from 49.73 to $29.75 \%$. The largest differences were in chestnut soil - from 50.46 to $26.87 \%$. Less porosity (by 7.2) was in soil, located in the zone of influence of the forest belt. The level of soil nitrification capacity is closely correlated with the level of humus content in them $(r=0.64)$. 